$\triangle C T A \mathbb{N} E O P H I L O L O G I C A$

UDK: 791.223.1:821.111(73).09

DOI: 10.4312/an.50.1-2.83-94

\title{
The Iconic American Western in Film and Literature
}

\section{Ali Shehzad Zaidi}

\begin{abstract}
This essay examines representative stories of the American Western genre in both film and literature in light of various literary influences, including The Bible and classical epics such as Gilgamesh, The Iliad, and The Odyssey. These stories relate the dynamic tensions of characters caught between righteous and unrighteous anger, between home and longing for the road, and between the imperative to survive and the impulse to sacrifice oneself for others.
\end{abstract}

Keywords: American Western, The Western, Gilgamesh, High Noon, Hombre, The Iliad, The Odyssey, Shane, "The Tin Star," Unforgiven 
The Western is a genre that explores our relationship to the land, community, and self. Generally regarded as unique to the United States, the Western has literary forbears that share its epic representation of the themes of friendship and anger. This essay examines four iconic stories of the American West, as portrayed in two novels, a short story, a movie script, and their film incarnations. In these stories, violence may serve to restore a fragile social order or alternately convey the rage inherent in a corrupt society.

The Bible is a dominant influence in the genre of the Western. The hero of the Western is sometimes given to the kind of retributive justice described in The Old Testament: "eye for eye tooth for tooth" (Exodus 21:24), but often shows forbearance under provocation, heeding Jesus' admonition to turn the other cheek. However, when compelled to fight, the hero wreaks terrible vengeance on his enemies in order to uphold the communal good and redress injustice. At such moments of courage and self-sacrifice, the hero appears semi-divine. Friendship has a special place in stories of the The Old Testament such as the one between Jonathan and David (1 Samuel 18-20). The Old Testament condemns unrighteous anger in such passages as Psalms 37: 7-8 ("Cease from anger, and forsake wrath./ Fret not yourself; it does nothing but harm; / For evildoers shall be cut off; While those who wait upon the LORD shall possess the land") and Proverbs 15:1 ("A gentle answer turns away wrath; But harsh words stir up anger").

The epic Gilgamesh is another literary precursor of the Western. Its earliest extant texts are from around 2100 BC (Mitchell 5). Gilgamesh represents the transition of humanity from a savage to a civilized state. This epic prefigures the tension within the cowboy, between the longing for freedom and his search for home and community. The taming of the West implies the taming of men; and this very process defines Gilgamesh. When Gilgamesh, the king and protector of the city of Uruk, hears of the approach of Enkidu, a savage and powerful man of mythical powers and proportions, he sends a priestess, Shamhat, to tame Enkidu through her love-arts. Enkidu's formidable powers are attenuated through the sexual pleasure that he experiences with the priestess after which Enkidu's "life-force was spent, / his knees trembled, he could no longer run / like an animal, as he had before... he knew that his mind had somehow grown larger, / he knew things now that an animal can't know" (Gilgamesh 79). The eponymous hero-king vanquishes Enkidu in a ferocious battle after which they become best friends. Their archetypal rivalry and friendship anticipates the male bonding seen in Westerns.

The Homeric epics, composed about the eighth century BC, also anticipate the narratives of violent masculinity in the Western. The Iliad does not glorify war. Instead the epic portrays warriors as petulant, childish, and given to self-destructive rage during the Greek siege of Troy, as can be seen in the epic's opening passage: 
The rage of Achilles - sing it now; goddess, sing through me the deadly rage that caused the Achaeans such grief and hurled down to Hades the souls of so many fighters, leaving their naked flesh to be eaten by dogs and carrion birds, as the will of Zeus was accomplished. (Iliad I: 1-5)

Rage is Achilles' vulnerability, symbolized by his heel, the only part of his body in which an arrow can kill him, hence the expression Achilles heel. The Trojan War reaches a turning point when the Trojan prince Hector slays Patrocles a close friend of the Greek warrior Achilles. This prompts Achilles to join the war and kill Hector, whose corpse he drags behind his chariot. Although he does not possess the self-mastery that characterizes the archetypal hero, Achilles nonetheless returns Hector's corpse to his grieving father, King Priam. Another Homeric epic, The Odyssey, tells of the survival, endurance, and resourcefulness of a Greek king who embarks on a ten-year journey home after the Trojan War. The opening lines of The Odyssey characterize its hero:

Tell me, Muse about the man of many turns, who many

Ways wandered when he had sacked Troy's holy citadel;

He saw the cities of many men, and he knew their thought;

On the ocean he suffered many pains within his heart,

Striving for his life and his companions' return. (The Odyssey I. 1-5)

Odysseus possesses the divine restlessness of the cowboy who is at the same time drawn to family and community.

A famous short story that dramatizes this tension between yearning for freedom and duty to community is John M. Cunningham's widely anthologized "The Tin Star" which first appeared in Collier's Weekly in 1947 and which pays homage to its literary ancestors. This tale of an aging sheriff, who dies in a showdown with a recently pardoned criminal and his gang of outlaws, was reincarnated in the film High Noon (1952) which won four Academy Awards. "The Tin Star" opens in medias res: "Sheriff Doane looked at his deputy and then down at the daisies he had picked for his weekly visit, lying wrapped in newspaper on his desk. 'I'm sorry to hear you say that, Toby. I was kind of counting on you to take over after me." As the story unfolds, the reader learns that Jordan, an outlaw that Sheriff Doane had sent to jail, has been freed early and is on his way to town where he is likely to provoke a duel with the sheriff. Doane intends to lay the daisies on his wife's grave. Flowers symbolize life's beauty and evanescence (Ferber 74-76). The daisies, which "were drooping markedly" as the sheriff leaves his office and heads for the cemetery, anticipate his death ("Tin Star" 214). 
The sheriff is handicapped because he suffers from gout, making it difficult to handle his gun, and because the residents of the town are too afraid to assist him. The mayor comes to the office to persuade the sheriff to leave town rather than face death. Shortly afterwards, a second deputy named Staley stops by to tender his resignation. Doane is resolved to stay but laments his thankless job: “They don't even hang the right ones. You risk your life catching somebody, and the damned juries let them go so they can come back and shoot at you. You're poor all your life, you got to do everything twice, and in the end they pay you off in lead. So you can wear a tin star. It's a job for a dog, son" ("Tin Star" 209). Toby as well harbors no illusions about his job, which he describes as "trying to keep the law so sharp-nosed money-grabbers can get rich" ("Tin Star" 209), yet the deputy, like his boss, refuses to quit in the face of mortal danger. Theirs is the timeless lament of the public servant who longs for freedom but is compelled to protect his community, a dynamic tension that harkens back to the characters in Gilgamesh and the Homeric epics.

During the office scene, the sheriff remarks to his deputy "Maybe the pen changes a man" ("Tin Star" 211). The line refers both to the sheriff's forlorn hope that Jordan might have become reformed during his time in jail, and to the writer's craft that made "The Tin Star" exemplary in its genre. Because he represents the law, Sheriff Doane must restrain his anger, in keeping with the lessons imparted by The Bible and The Iliad. When Doane reaches his wife's grave in a cemetery at the town's outskirts, Jordan shows up to goad him into a fight. When asked if he had any objections to Jordan being in town, Doane declines the challenge, saying "You haven't done anything, Jordan. Except get drunk. Nothing to break the law" "Tin Star" 215). Jordan continues to taunt him, setting the stage for the showdown in town during which an already wounded Sheriff Doane will take a bullet in the back and give his life to save his deputy. With the threat to the town removed, Toby immediately assumes the role of his savior and mentor when he becomes the new sheriff.

Throughout the story, Sheriff Doane is attuned to the presence of larks that soar above the squalor of the violent town like ethereal beings. The lark symbolizes the inner sense of freedom and integrity that enables Douane to endure his job. The sheriff tells his deputy,

It's all for free. The headaches, the bullets and everything, all for free. I found that out long ago... But somebody's got to be around and take care of things... I like it free. You know what I mean? You don't get a thing for it. You've got to risk everything. And you're free inside. Like the larks. You know the larks? How they get up in the sky and sing when they want to? A pretty bird. A very pretty bird. That's the way I like to feel inside. ("The Tin Star" 210) 
These words convey the sense of a man who is confined by his job but who remains spiritually free and who is at peace despite the stress of the upcoming showdown. The image of his outstretched hands suggests that Doane is a Christ-figure:

Doane's eyes came again to the flowers, and some of the strain went out of his face. Then suddenly his eyes closed and he gave a long sigh, and then, luxuriously, stretched his arms. "Good God!" he said, his voice easy again. "It's funny how it comes over you like that." He shook his head violently. "I don't know why it should. It's not the first time. But it always does." ("The Tin Star" 212)

The words "It's not the first time" suggest a recurring pattern of suffering for the sheriff who finds solace in the beauty of the natural world.

The lark is associated with yearning and ascension to heaven (Ferber 104-05). Doane's ability to rise above bitterness and self-pity into a realm of love recalls the words of Shakespeare's famous sonnet:

When, in disgrace with fortune and men's eyes,

I all alone beweep my outcast state,

And trouble deaf heaven with my bootless cries,

And look upon myself, and curse my fate,

Wishing me like to one more rich in hope,

Featur'd like him, like him with friends possess'd,

Desiring this man's art and that man's scope,

With what I most enjoy contented least;

Yet in these thoughts myself almost despising,

Haply I think on thee, and then my state,

Like to the lark at break of day arising

From sullen earth, sings hymns at heaven's gate;

For thy sweet love remember'd such wealth brings

That then I scorn to change my state with kings. ("When in disgrace")

The lark augurs glad tidings, abundance, and the lifting of earthly burdens (Palmer 212). The image appealed to the Romantics: Shelley and Wordsworth both wrote poems titled "To the Skylark" in which the skylark embodies happiness and light. When, at the cemetery, the drunken Jordan takes aim at the lark in an effort to show that he is sober enough to fight, he mumbles, "Damn it, I can't see!" when he misses it ("The Tin Star" 215). Jordan's words recall both his failure to kill the lark as well his own wretched spiritual state. At the end of the story, Douane's last words are about a "pretty bird" - the lark - as he sacrifices his life for Toby, his deputy, a friend who will carry on his legacy. 
In the film High Noon (1952), the stakes are higher for the sheriff since he is newly married and has even more reason to quit his job. The sheriff defers domesticity just long enough to fulfill his task. Despite the cowardice of the townspeople and his isolation in the face of danger, the sheriff fulfills his destiny and rids the town of the criminal gang. At the climax, his wife intervenes with a shotgun to save her husband's life, ferociously shooting a gunman in the back, against her own Quaker principles. The sheriff tosses his badge aside in disgust but only after he has accomplished his bloody task. Like other Hollywood films produced in the midst of the Cold War, High Noon performs an ideological function by turning a pacifist into a violent heroine. The film lacks the rich symbolic depth of "The Tin Star" in which the sheriff's sacrifice lends the story poignancy and meaning.

Jack Schaefer's novel Shane (1949) is another trailblazing story about a reluctant gunslinger, set in Wyoming in 1889, a time when the end of the open grazing range was in sight. The renowned A. B. Guthrie Jr. wrote the screenplay of the 1953 film by the same name. The novel received critical acclaim while the film received an Academy Award for cinematography. The eponymous hero is in every sense the very opposite of the braggarts who like to fight. To the rancher's men, he initially seems like a peaceful cowhand, but Shane soon proves that he too can brawl and handle a gun. Shane refuses to be provoked, containing his anger, but he will resort to violence when he must.

In the novel, we see the mysterious protagonist of Shane through the eyes of Bob Starrett who was a boy at the time of the story but a man at the time of its telling. Shane appears seemingly from nowhere and strikes up a friendship with Bob's father, Joe Starrett, one of several homesteaders who had come into conflict with a powerful rancher named Luke Fletcher. Shane is the kind of archetypal cowboy that Philip Ashton Rollins describes as "a man with guts and a horse" and who possesses the reserve that, according to Rollins, typifies the cowboy (66-67). Shane's monosyllabic, and almost certainly pseudonymous, single name, heightens the man's mystery. As Rollins points out, in the West it was customary "to accept at face value whatever name the stranger or acquaintance cared to put forth as his own" (68).

Shane is invited to remain with the Starrett family and he soon becomes a close family friend. Marian, Joe's wife, is attracted to Shane and the novel dramatizes her inner struggle through dialogue, such as in this exchange between Marian and Joe:

"Do you think I don't know, Marian?"

"But you don't. Not really. You can't. Because I don't know myself." (Shane 203)

The novel also leaves much to the reader's imagination with regard to the facial expressions in the scene in which, after the brawl with Morgan's men, Bobby hears his mother exclaim, "Did ever a woman have two such men?" (Shane 202). The 
narrator, the adult Bobby, then relates how "The two men stared at her and then at each other in that adult knowledge beyond my understanding" (Shane 202). Shane's ferocious combat with Joe Starrett over who would get to fight Fletcher's men recalls the epic combat between Gilgamesh and Enkidu. Shane becomes Joe's true friend and will risk his life to protect his host and the homesteaders.

The novel conveys Shane's rootedness in the land through his language, such as when he tells Bobby, "Fletcher has made this a straight win or lose deal. It's the same as if he'd kicked loose a stone that starts a rockslide and all he can do is hope to ride it down and hit bottom safe" (Shane 206). His language has an earthy, pictorial character that creates a vivid connection to place that is epitomized in the reference to the stump that cannot be budged despite Joe's strenuous efforts. Shane overcomes the allure of domesticity in order to fulfill his calling. Shane safeguards the homesteaders but declines to stay on, in part because he has killed several men which would bring down the law on him. Ever a man of mystery, Shane disappears into the mountains from which he had emerged, ready to resume, like Odysseus, his wanderings.

Owing in part to the nature of the medium, the film departs from Jack Schaefer's novel in small ways. In the film, Joe Starrett's son is named Joey possibly to convey the son's resemblance to a father who is trusting and simple and good. The film's visual power is apparent from the outset when Joey aims his unloaded rifle at a deer only to find Shane in the sights. This dramatic moment suggests all at once Shane's hunted aspect, a sense of menace, and the element of surprise. The film achieves the same effect in the novel, that of Marian as an unknowable woman, not so much through dialogue as through what is left unspoken. After the ferocious fight in which Shane knocks Joe unconscious, Marian and Shane shake hands and exchange looks. Is Marian's expression that of a wife thankful that a stranger has prevented her husband from dying in a shoot out? Or is her look that of a complicit lover?

In the film, unlike in the novel, Joe and Shane manage to budge the stump. The moment is emblematic of the friendship and power that enables them to overcome Fletcher's hired men after a series of bloody encounters. Like the novel, the film bonds the viewer to the land. In a funeral scene, the land is almost sentient as the camera sweeps across the mourners with a mare that is suckling a foal in the foreground and snow-clad Wyoming mountains in the distance. The film preserves a sense of mystery as Shane rides off into the twilight, transfigured by the moonlight. The film masterfully furthers the Shane legend and complements the novel.

The desert is more than just a decorative backdrop in Elmore Leonard's novel Hombre (1961) and in its film version (1967) by the same name. Water is a precious resource whose scarcity spurs the dramatic tension. The suffering of the thirsty travelers parallels that of the Apaches who have been banished to a 
reservation where a corrupt government agent, the aptly named Dr. Favor, has stolen the funds that might have provided for their bare subsistence. The film's opening scene, absent in the novel, prefigures both the role and fate of the central character, John Russell, a white man who had been raised among the Apaches. As Russell and a fellow Apache look on, a black stallion leads a herd of horses towards a water hole. When the horses begin to drink at the water hole, Russell bars a gate to trap the horses inside the corral. Russell will be trapped by circumstances when he leads a group of travelers to safety in the desert at the cost of his own life.

In the novel, the MacLaren girl, who had spent several months as a captive of the Apaches, provides insights into the motivation and character of Russell. She also serves as a bridge between the world of white Americans and that of the Apaches. She refuses to side with Dr. Favor against Russell when Favor tries to hold on to the saddlebag under the pretense that "It's my money." Upon hearing this, the MacLaren girl bursts out: "Your money. After you stole it! We're supposed to side with you to protect money you stole" (Hombre 95). Her absence from the film detracts from our understanding of Russell, for in the novel, it is the MacLaren girl who gives Russell hope for a future of moral renewal.

The film preserves some of the novel's best dialogue, such as when Favor utters a richly evocative line just before he takes Mendez's shotgun: "Where money is concerned you don't know anybody" (Hombre 122). His words reveal more than just his own greed. They also anticipate our discovery of the hidden motive that compels Russell to risk his life, namely, the starving Apaches on the reservation. Another instance of engaging dialogue is when Russell tells his companions to watch out for Dr. Favor: "If he tries to leave with nothing, shoot him once," If he takes the saddlebag, shoot him twice. If he picks up the water, empty your gun" (Hombre 100). In the film, Russell delivers the line deadpan. However, the film necessarily omits the subsequent reflections of the first person narrator, Carl Allen, a former employee of a nearby stagecoach company: "(I have thought about those words since then and I am sure Russell was having a little fun with us when he said that. Part serious, part in fun. But can you imagine joking at a time like that? That of course was the reason no one even smiled. He must have thought we were dumb.)" (Hombre 100-101). This last sentence recalls a key narrative technique of many American Western writers, namely the use of a first person narrator whose limited understanding of the events at hand compels the reader to engage more deeply with the story to help create its meaning. Though somewhat myopic, Allen comes to sense the measure of Russell's sacrifice for his people.

The film expertly uses dialogue and the starkly barren landscape to characterize the mysterious John Russell. In a desert scene, Jessie, the former caretaker of the boardinghouse that Russell had promptly sold upon assuming ownership, tells Russell: "You haven't moved a muscle in the last hour. Don't you ever get tired? 
Don't you ever get hungry? Don't you ever get thirsty? Are you for real?" (Ritt). Her words allude to the man's strange persistence which, we will learn, arises from a quest for justice. The travelers misjudge Russell when he declines to surrender the money in exchange for the life of Mrs. Favor. To the MacLaren girl in the novel and Jessie in the film, Russell appears callous, even inhuman, towards the woman tied up by the bandits and baking in the hot sun when he says "Go ask that woman what she thinks of human life. Ask her what a human life is worth at San Carlos when they run out of meat" (Hombre 161).

Russell had maintained his cool in the waiting room as he awaited the stage coach. He had refused to intervene when a gunslinger intimidated a passenger to give up his ticket. This is because acting in anger would have interfered with his larger purpose and much greater justice. In the end, Russell saves the life of Mrs. Favor but loses his own. Both the film and novel heighten Russell's mystery by sparing us the formulaic last words of a dying hero. The fatally wounded Mexican asks to be told the name of the man that he just killed, affirming Russell's grandeur. The survivors will safeguard the money and bring Dr. Favor to justice, having learned that Russell had never intended to steal it. In Hombre, violence ultimately proves restorative, tracing the outline of a man whose courage was forged in the raw injustice meted out to indigenous people.

Unforgiven (1992), a commercial success that won four Academy Awards as well as critical acclaim, was directed by Clint Eastwood who had been given its unproduced film script a decade earlier. This bleak film is an unforgiving portrait of Wyoming in 1881. It subverts the devices associated with the Western, undercutting the notion of the redemptive power of violence. The film strips the American West of its Hollywood glamour, revealing that region to be violent and unredeemed.

Unforgiven opens with a harrowing scene in which a cowboy repeatedly slashes a prostitute with a knife. In the aftermath of the crime, the sheriff arrives and attributes the deed to "hardworking boys that was foolish" and had gotten carried away. Impunity, we soon discover, extends to the sheriff himself. Sheriff Daggett is a sadistic brute who rules the town of Big Whiskey unchecked. The prostitutes cannot expect justice from the authorities. Their haggard faces reveal longstanding sadness and despair. The women are trapped in a loveless world. They are slaves to the saloon owner and the raunchy cowboys who take their pleasure with them. The bitter women offer a one thousand dollar reward to whoever kills the two men responsible for harming the unfortunate girl. "Just because we let them ride us as horses, doesn't mean we have to let them brand us as horses," one prostitute exclaims (Unforgiven).

Will Munny, a former hired killer, hears about the reward from a young man nicknamed the Schofield Kid. Will ekes out a living as a pig farmer, an occupation 
perhaps best suited to his erstwhile profession. His wife is dead and he has two children to support. The Schofield Kid pretends that he has killed five men, believing that a history of violence raises his stature. Will does not romanticize murder. He recalls that his deceased wife had cured him of wickedness. Will had nearly been killed in one encounter. "I thought I was dead," Will recalls, "but I found out I was just in Nebraska" (Unforgiven).

The Schofield Kid, ever eager for a fight, is fascinated by Will's gun slinging past, and asks Will if he had been scared during one of his notorious fights. Tellingly, Will replies, "I can't remember. I was drunk at the time" (Unforgiven). In this fashion, Unforgiven conveys an anti-heroic vision of the American West. The film exposes the falsification of the American West through the mythologizing of violence. An awe-struck biographer discovers the complications of truth when he hears another version of English Bob's life story from Sheriff Daggett, who had driven the gunslinger out of town. Unlike formulaic westerns in which killing appears as a kind of sport, Unforgiven reminds us that killing is unnatural and that fear accompanies violence. Will readily confesses, "Everybody can be scared. If he wasn't scared then he just wasn't no carpenter" (Unforgiven). This allusion to Jesus confirms fear as human.

We soon discover in this film that violence is not a regional pastime, but a national pathology. The passengers in the train headed to Big Whiskey discuss the assassination of President James Garfield which took place in 1881, the year of the events in the film. English Bob uses the occasion to pick a fight. He tells the passengers that in England, as opposed to the United States, it would be considered uncivilized to shoot persons of substance. Violent death, English Bob declares, ought to spare the affluent. He proposes that the United States would be better governed by a king. His provocative remarks are meant to provide an opportunity for Bob to show off his shooting skills.

Together with the Schofield Kid and his former partner Ned Logan, Will hunts the two cowboys responsible for slashing the girl. Logan no longer has any taste for killing and pulls out of the deal. Nonetheless, Will and the Schofield Kid manage to avenge the prostitute and collect the reward money. The financial windfall comes at a terrible price. Logan is caught and tortured to death by Sheriff Daggett. Will risks all to avenge his friend in a shoot out that, out of sheer luck, culminates in the death of the sheriff and several of his cronies. In a memorable scene, Will responds to Sheriff Daggett plea, "I don't deserve to die this way," saying "deserving has got nothing to do with it" just before he kills him. The violence in the film is as nightmarish as that in The Iliad.

There is a wistful sense of possibility when the slashed girl meets Will. But the two are not destined to love. There is no place for love in their world. After the murder of the two cowboys that had slashed the prostitutes, angry townsmen 
hurl a brick through the window of the saloon, shouting "murdering whores." The girl will live out her life trapped and unloved. Will, it is said, made his way to San Francisco, escaping the unrelieved grimness of the American West. The meaning of the title of Unforgiven extends beyond lives of its unredeemed characters to indict a corrupt society that deserves to remain unforgiven. The film memorably strips violence and the American West of glamour, revealing deep underlying human sorrow.

The archetypal patterns that give the American Western transhistorical significance continue to remerge in other guises as we explore new frontiers such as in space travel or in virtual worlds. The themes of friendship, courage, self-mastery, violence, redemption, community, and wanderlust that are the enduring legacy of the American Western are also integral to ancient literary traditions. In reaffirming our bond to the earth and to others, the American Western deserves to remain etched in our collective cultural memory.

\section{WORKS CITED}

Cunningham, John M. "The Tin Star." In The Western Story: Fact, Fiction and Myth. Ed. Philip

Durham and Everett Jones. New York: Harcourt Brace Jovanovich, 1975: 209-22. Ferber, Michael. A Dictionary of Literary Symbols. Cambridge, UK, Cambridge University Press, 1999.

Gilgamesh. Trans. Stephen Mitchell. New York, Atria, 2004. High Noon (film). Dir. Fred Zinneman. Stanley Kramer Productions, 1952.

Hombre (film). Dir. Martin Ritt. Twentieth Century Fox, 1967.

Homer. The Iliad. Trans. Stephen Mitchell. New York: Free Press, 2011.

Homer. The Odyssey. Trans. Albert Cook. New York: W. W. Norton, 1967.

Leonard, Elmore. Hombre. New York: William Morrow, 2012 (1961).

Palmer, Jessica David. Animal Wisdom. London: HarperCollins, 2001.

Peoples, David Webb. Unforgiven (film script), 1984. Eastwood The World Wide

Web Page. http://www.clinteastwood.net/filmography/unforgiven/script/unforgivenscript.txt (Accessed 20 Sept. 2016).

Rollins, Philip Ashton. The Cowboy. Norman: University of Oklahoma Press, 1997 (1936).

Schaefer, Jack. Shane. Ed. James C. Work. Lincoln: University of Nebraska Press, 1984.

Shakespeare, William. "When in disgrace with Fortune and men's eyes." In Literature: Craft E' Voice. Ed. Nicolas Delbanco and Alan Cheuse. New York: McGraw-Hill, 2012: 843. 
Shane (film). Dir. George Stevens. Paramount Pictures, 1953.

The Old Testament: An American Translation. Ed. J. M. Powis Smith. Chicago:

University of Chicago Press, 1927.

Unforgiven (film). Dir. Clint Eastwood. Warner Brothers, 1992.

Ali Shehzad Zaidi

State University of New York at Canton zaidia@canton.edu

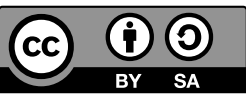

\section{Ikonični ameriški western v filmu in književnosti}

Prispevek raziskuje žanr ameriškega westerna skozi reprezentativne zgodbe v fil$\mathrm{mu}$ in $\mathrm{v}$ književnosti. Te zgodbe prikazujejo dinamično notranjo napetost junakov, ki jih po eni strani vleče domov in ki po drugi strani vseeno hrepenijo po odhodu $\mathrm{v}$ širni svet.

Ključne besede: Epo Gilgamešu, Iliada, Hombre, Točno opoldne, Shane 